\title{
DETERMINATION OF STARCH ACCORDING TO THE PRINCIPLE OF IODINE COL.ORIMETRY.
}

\author{
Lauri Paloheimo \\ Department of Animal Husbandry, University of Helsinki.
}

Received 11. 8. 1948 .

The general features of the method to be described here were first published by the author in 1930 (1). The further developing of the method was reported by the author together with IrJa Palohermo in 1931 (2), and a modification for the Pulfrich-Photometer in the same year by the author together with I. Antila (3). Since then the method has been frequently used in this laboratory, especially for estimation of starch in potatoes, and during the war it was used for the control of the oatmeal-foddercellulose mixtures of the army. Because the method since its introduction has undergone some alterations it may be appropriate to record as well the principles as the details of the method in this paper.

\section{General features of the method.}

From the heading of this paper one may conclude that our method is founded on the known colour reaction of starch with iodine. In fact, here is not a question of the blue colour of the absorption product of the starch with iodine, but of the reddish colour produced by iodine in solutions containing dextrins derived from starch by a cautious treatment with acid.

The solutions to be coloured with iodine are in fact prepared by boiling the sample to be analyzed in a diluted acid solution. The aim of this treatment is to liberate all the starch from the plant cells. The simple boiling in water is not sufficient for this purpose because the thick starch slime is unable to penetrate the cell walls through their narrow pores. The rise of the $\mathrm{H}^{\prime}$-concentration, however, brings about a more far-reaching hydrolysis of the starch, and the dextrins formed are capable of penetrating the cell walls. The 0,05-normal solution of hydrochloric acid is adequate for this purpose if a large volume of it is used. The latter circumstance is important firstly because the rise of the dextrin concentration disturbes the liberation of starch from the cells and secondly, because the large volume acts as a buffer against the $\mathrm{pH}$-changing effect of certain constituents of the matter to be analyzed. - After boiling, the solution is diluted with water and coloured with iodine. 
For the colorimetric measurement a standard starch solution is prepared containing $5 \mathrm{mg}$. starch in $100 \mathrm{ml}$. In the preparation of this solution the circumstances ought to be the same as in the preparation of the solution to be analyzed. In the colorimetric measurement the both solutions must have the same iodine concentration, but the starch concentration in the solution to be examined must be higher than in the standard solution. Therefore, the coloration brought about by the iodine is more intensive in the former. Also the tone of colour is different in the two solutions, so that the solution with the higher starch concentration, i.e. the solution to be examined, obtains a more bluish tinge. Two solutions which contain both iodine and starch (or dextrins of the starch) can have the same tone and intensity of colour only on condition that as well the concentration of iodine as that of starch (dextrins) is equal in the both solutions. If one would dilute with water the darker of the above mentioned solutions, its colour intensity would go down but it would never attain the tone of colour which is peculiar to the standard solution. This is only natural because in consequence of the dilution with water the iodine concentration of the diluted solution becomes lower than that of the standard solution. If, however, instead of water an iodine solution is used, which has the same iodine concentration as have both the standard solution and the solution to be examined, the iodine concentration of the latter remains constant during the dilution, whereas the starch concentration continually falls. Thus by continued dilution it is possible to attain a point at which the starch concentration as well as the iodine concentration of the diluted solution is the same as in the standard solution. At this point, provided that the original surplus of starch in the solution to be examined was not great, the two solutions are of the same colour. On the bases of the degree of dilution needed for the attainment of this isochromatic point one calculates the starch content of the solution to be examined, and finally of the matter to be analyzed.

The use of an iodine solution as diluent in the colorimetric measurement forms the very essential point in our method which we have not noticed in the earlier propositions for the iodine colorimetric estimation of starch.

\section{Detailed description of the method.}

Iodine solution. - A 5 per cent. solution of potassium iodide is saturated with iodine. For the colorimetric use 1 volume of this solution is diluted with 3 wolumes of water. The preparation of the iodine solution does not require any great precision. It is only important that the standard solution and the solution to be examined are coloured with the same iodine solution.

Standard solution. - A sample of $500 \mathrm{cc}$. starch, if possible of the same botanical origin as the matter to be analyzed, is placed in a $600 \mathrm{cc}$. beaker and mixed with some cold water. The beaker has a mark at $400 \mathrm{cc}$. Boiling water is added to the beaker not quite until the mark and the mixture is brought up to boil. $20 \mathrm{cc}$. of 1-normal hydrochloric acid is added and made up to $400 \mathrm{cc}$ with boiling water. The mixture is boiled for 30 minutes by compensating the loss of evaporation with boi- 

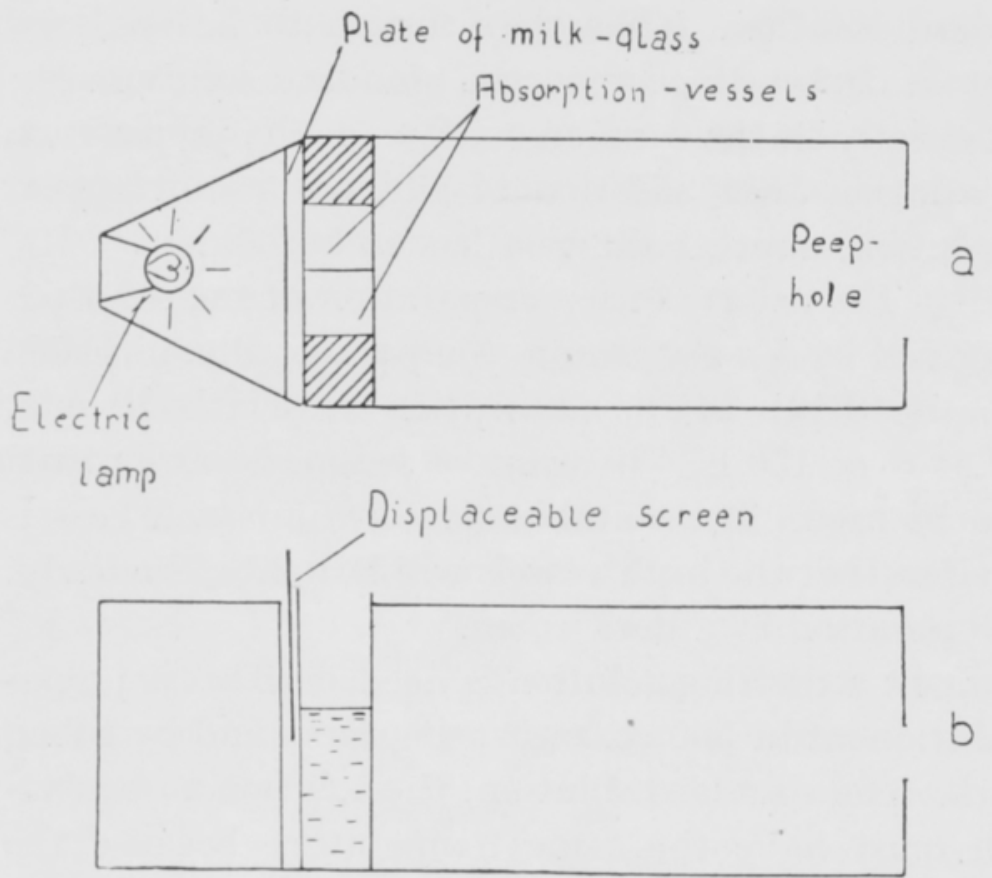

Fig. 1. Comparator. a. Axial section parallel to the ground-plan. b. Longitudinal section cleaving one of the absorption vessels.

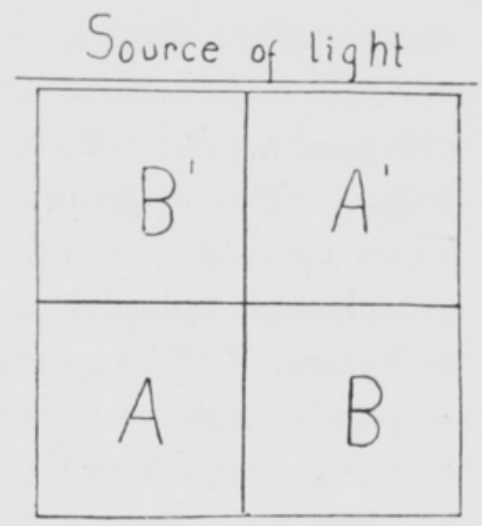

Fig. 2. The arrangement of the vessels when compensators are used. $\mathrm{A}$ and $\mathrm{B}$ as in Fig. 1. $\mathrm{A}^{1}$ like $\mathrm{A}$ without iodine. $\mathrm{B}^{1}$ like $\mathrm{B}$ without iodine.

ling water. After removal from above the flame the mixture is allowed to stay in the beaker on the table for 3 minutes $^{1}$ ) before it is cooled in running water. After cooling, the mixture may stay, if necessary, without disadvantage in room temperature until the following day. Immediately before the colorimetric measurement it is transferred into 1 litre measuring flask and the flask made up to the volume. $25 \mathrm{cc}$. of the contents are transferred into another $500 \mathrm{cc}$. measuring flask and about $400 \mathrm{cc}$. of water are poured upon. $5 \mathrm{cc}$. of iodine solution are added under simultaneous shaking. The flask is at once made up to the volume with water and thoroughly shaken. The solution is ready for colorimetric use.

The solution to be examined. - When analyzing cereal products or other airdry materials it is advisable to weigh $1 \mathrm{~g}$. of finely ground matter. From potatoes or other succulent products $5 \mathrm{~g}$. of grated pulp are weighed. If the material is not sufficiently finely divided, it must be crushed in a mortar. The sample is placed in a $600 \mathrm{cc}$. beaker and treated in the way described in the preceding chapter. However, after boiling with diluted acid it is in many cases advisable to filter the mixture through a Büchner funnel equipped with silk gauze and siliceous sand. The fiitering takes about 3 minutes. Immediately before the colorimetric measurement the mixture is transferred into a 1-litre measuring flask and the flask made up to the volume. As the starch content of the treated sample is usually approximately known, it is not difficult to predict how many cubic centimetres of the solution are to be taken for the second dilution. The pipetted amount must be large enough to ensure to the solution to be coloured with iodine a greater starch concentration

$\left.{ }^{1}\right)$ That is the time needed for the filtration of the solution to be examined. See below. 
than is appropriate to the standard solution. Thus the solution to be analyzed receives, when coloured with iodine, a darker tinge than the standard solution. The coloration by iodine is performed exactly in the same manner as in the preparation of the standard solution. If the solution after addition of iodine does not appear to be darker than the standard solution, another dilution has to be made.

The colorimetric measurement. - The colorimetric comparation of the solutions coloured with iodine can be performed by a very simple comparator illustrated in Fig. 1. The appropriate photometric depth of the absorption vessels is $40 \mathrm{~mm}$. Their capacity should be somewhat over $150 \mathrm{cc}$. In want of prismatic absorption vessels also cylindrical vessels can be used. The suitable diameter for such vessels is $50 \mathrm{~mm}$. The lamp must be placed so that the both vessels will be lighted similarly. It is advisable to perform the comparation in a dark room.

For the colorimetric measurement a diluting solution is needed. This is prepared by pipetting $5 \mathrm{cc}$. of iodine solution into a $500 \mathrm{cc}$. measuring flask and by filling the flask with water upto the mark. The standard solution, the solution to be examined, and the diluting solution must have the same temperature because the absorption product of starch with iodine is sensitive to temperature.

Into the one absorption vessel (A) about $150 \mathrm{cc}$. of the standard solution are poured and into the other $(\mathrm{B})$, which is beforehand moistened with the solution in question, exactly $100 \mathrm{cc}$. of the solution to be examined. As mentioned above, the latter solution is darker than the former. It must now be diluted with the diluting solution until the colour intensity of the standard solution is reached. Then the solution of the vessel $\mathrm{B}$ is poured into a wet measuring cylinder of small calibre and measured therein. When comparing the solutions in the comparator, one must, if the solution $\mathrm{B}$ does not attain exactly the tinge of the standard solution, take into consideration only the illuminating power of the solution, i.e. one should try to see achromatically. If the volume of the solution B, when diluted in comparator, rises to $150 \mathrm{cc}$. or over, a more diluted solution to be examined is to be prepared. In this way the solution B usually attains exactly or nearly the tinge of the standard solution.

When materials with a low starch content are examined it may occur that the solution in the vessel B proves to be turbid or contains coloured substances besides those induced by iodine. In such cases compensators are to be used at the comparation. The arrangement is seen in Fig. 2. The solutions B and $\mathrm{B}^{1}$ are to be diluted simultaneously, the former with diluting solution containing iodine and the latter with a corresponding amount of water.

The calculation of the starch content of the matter to be analyzed. - The content of starch of the matter to be analyzed is calculated as follows: It is presumed that the dry matter content of the starch used for the preparation of the standard solution is a per cent. Thus the first measuring flask contains $\frac{\mathrm{a} \cdot 500}{\mathrm{IOO}}=5 \mathrm{a} \mathrm{mg}$. starch and each cc. of its contents a/100 mg. The second measuring flask contains $25 \mathrm{a} / 100=\mathrm{a} / 4 \mathrm{mg}$. starch and each cc. of its contents, i. e. of the standard solut on, a/2000 mg. Further it is supposed that the ultimate volume of the solu- 
tion in the absorption vessel $\mathrm{B}$ is $\mathrm{b}$ cc. Each cc. of this solution contains the same quantity of starch as $1 \mathrm{cc}$. of the standard solution, i. e. a/2000 $\mathrm{mg}$. and the vessel in all ba/2000 $\mathrm{mg}$. This is $1 / 5$ of the starch content of the second measuring flask used in the preparation of the solution to be examined. Thus the flask in all contained $5 \mathrm{ab} / 2000=\mathrm{ab} / 400 \mathrm{mg}$. starch. It is supposed that in preparing the solution to be examined c cubic centimetres were pipetted off from the first measuring flask into the second. These c cubic centimetres contain ab/400 mg. starch and the first flask in all $500 / \mathrm{c} \cdot \mathrm{ab} / 400=5 / 4 \mathrm{ab} / \mathrm{c} \mathrm{mg.:}$ This is also the starch content of the weighed sample.

The starch of the same botanical origin as the matter to be analyzed not being obtainable the standard solution is to be prepared of a botanically foreign kind of starch. Then, however, a coefficient is needed which is obtained by comparing standard solutions prepared from different kinds of starch. We include here some numbers indicating the amounts of different kinds of starch which give the same colour-intensity as $100 \mathrm{~g}$. of the starch of wheat kernels:

$\begin{array}{llr}\text { rye starch } & \ldots \ldots \ldots & 101 \mathrm{~g} . \\ \text { barley " } & \ldots \ldots \ldots & 97 \\ \text { oat } " & \ldots \ldots \ldots & 101 \\ \text { rice " } & \ldots \ldots \ldots & 109 \\ \text { potato " } & \ldots \ldots \ldots & 82\end{array}$

These equivalency numbers are calculated on dry matter basis.

\title{
REFERENCES.
}

(1) Paloheimo, Lauri. Zur Verwendbarkeit des jodkolorimetrischen Prinzips bei Stärkebestimmungen. Bioch. Zeitschr., 222, p. 150, 1930.

(2) Paloheimo, Lauri und Paloheimo, Irja. Beiträge zur Jodkolorimetrie der Stärke nach der Methode von Paloheimo. Bioch. Zeitschr., 238, p. 391, 1931.

(3) Paloheimo, Lauri und Antila, Irvo. Über die Anwendung des Pulfrich-Photometers bei jodkolorimetrischen Stärkebestimmungen. Bioch. Zeitschr., 238, p. 401, 19:1.

\author{
SELOST US. \\ JODIKOLORIMETRINEN TÄRKKELYSMÄÄRITYS. \\ LaUri Paloheimo. \\ Kotieläintieteellinen laitos, Helsingin Yliopisto.
}

Keittämällä $1 \mathrm{~g}$ tutkittavaa jauhetta $400 \mathrm{ml}$ :ssa 0.05 normaalista suolahappoliuosta saadaan tärkkelys dekstrininä vapautetuksi kasvisolukoista. Saadun liuoksen tärkkelyspitoisuus määritetään vertaamalla siitä valmistetun jodipitoisen liuoksen väriä määrätyllä tavalla valmistetun standardiliuoksen väriin. Vertailuun ryhdyttäessä tulee tutkittavan liuoksen olla tummempi (siis tärkkelysrikkaampi) kuin standardiliuos. Tutkittavaa liuosta laimennetaan tärkkelysvapaalla jodiliuoksella, jonka jodipitoisuus on sama kuin standardiliuoksen ja tutkittavan liuoksen. Laimennuksen aikana pysyy siis tutkittavan liuoksen jodipitoisuus kaiken aikaa samana, mutta tärkkelyspitoisuus alenee vähitellen. Laimennus lopetetaan niin pian kuin tutkittava liuos on saavuttanut standardiliuoksen värin. Koska liuoksilla nyt on sama väri ja sama jodipitoisuus, päätellään tästä, että myös niiden tärkkelyspitoisuus on sama. Tarvitun laimennussuhteen perusteella lasketaan tärkkelyspitoisuus. 